\title{
Using focused ethnography to understand brokering practices among international students
}

\section{ABSTRACT}

1.

2.

3.

4.

5.

6.

7.

8.

9.

10.

11.

12.

13.

14.

15.

16.

17.

18.
The academic challenges of international students, particularly those with English as an additional language (EAL), have been mostly researched in the context of the formal curriculum (e.g. classroom communication styles, reading and writing skills). These challenges include inadequate English proficiency and differing educational expectations, and being isolated from the host community. However, little is understood about students' informal academic learning outside the prescribed curriculum, in particular, their brokering practices. Brokering practices are help-seeking interactions that bridge gaps in the seekers' knowledge and understanding of new cultural practices thus enabling them to access resources they would find difficult to do so on their own. For EAL students, these help-seeking interactions may involve getting others to translate, interpret or explain particular aspects of the host academic environment. In this research, focused ethnography is used to investigate the nature of brokering practices among ten international EAL tertiary students during their initial academic semester of fifteen weeks. Focused ethnography specifically addresses constraints in the research context (e.g. time and access to informants), as well as capitalizes on technological tools such as digital recording devices. In seeking to understand brokering interactions and relationships students have with their brokers, conventional ethnographic methods were adapted, for example,

\section{KEYWORDS}

academic learning brokering focused ethnography informal learning international students methodology 
digital ethnographic methods were used instead of participant observation. Digital ethnographic methods allows a large amount of data to be recorded and reviewed, a feature of focused ethnography known as data intensity. While this form of intensity has been argued to compensate for a short period of research activity, this research suggests that another form of intensity - relational intensity - is just as important in addressing research constraints. Relational intensity refers to the researcher's ongoing responsiveness to the needs of research participants. The article concludes that future focused ethnographic research should consider both data-related and relational forms of intensity in addressing research constraints.

\section{INTRODUCTION}

Informal learning is recognized to be an important aspect of academic learning, but there is limited research investigating informal learning practices among international (English as an Additional Language (EAL) students. A useful concept to understand EAL students' informal learning practices is brokering, which can be understood as help-seeking social interactions. For EAL students, brokering often takes place when they encounter language or cultural barriers in accessing academic resources. They then seek help from particular others - brokers - because these brokers are able to translate information into the students' native language, or because they are able to explain the underlying meaning or implications of academic requirements.

Literature that alludes to EAL students' brokering practices suggests that social networks are important resources for seeking academic help. EAL students have been found to seek assistance from native-English speaking peers whom they perceive to have greater expertise, or from peers with whom they share similar backgrounds and experiences. However, the circumstances that motivate and sustain brokering interactions and relationships remain unclear as brokering interactions themselves have not been examined in much detail. Researching brokering practices, however, is challenging because of the implicit and unstructured nature of informal learning (Eraut 2004). With young adult learners, another challenge for researchers is that informal learning is likely to involve the routine use of technology-mediated communication tools such as computers and mobile phones (Helles 2012; Pink et al. 2015), thus increasing the taken-for-granted and invisible nature of brokering practices. A methodology known as focused ethnography has the potential to meet those challenges.

Focused ethnography adapts conventional ethnographic methods so as to addresses the specificity of cultural or social phenomenon to be investigated within a relatively short time period (Higginbottom et al. 2013; Knoblauch 2005). Adaptations include replacing participant observation with digital recordings of social interaction and behaviour (Knoblauch 2005) and using other digital ethnographic methods (Pink et al. 2015). Brokering practices can thus be potentially investigated by using recording devices that may be better suited to capture instances of informal learning.

This article discusses how researching brokering practices benefitted from the use of focused ethnography. The research was part of a Ph.D. study that examined brokering practices of ten international EAL students at a New Zealand university. Participants were mostly ethnic Chinese and data collection took place within their initial semester of studies, where one semester lasts for fifteen weeks. The research questions addressed the nature of
1.

2.

3.

4.

5.

6.

7.

8.

9.

10.

11.

12.

13.

14.

15.

16.

17.

18.

19.

20.

21.

22.

23.

24.

25.

26.

27.

28.

29.

30.

31.

32.

33.

34.

35.

36.

37.

38.

39.

40.

41.

42.

43.

44.

45.

46.

47.

48.

49.

50.

51.

52. 
1. brokering practices such as the characteristics of brokering interactions, and the reasons that motivated and sustained brokering relationships.

The article begins with a review of literature on brokering and focused ethnography, followed by a report on the methodological aspect of the research. It describes the background of the research context, explains the choice of research methods, and discusses the forms of intensity that arose in conducting ethnographic research with constraints in time and opportunities. The discussion on intensity highlights what Knoblauch (2005) terms data intensity - the large amount of digitally recorded material collected that can then be repeatedly reviewed and analysed. While data intensity was relevant to some aspects of this research, it was not sufficient in addressing the constraints of the research context. The research found that it was also important to consider relational intensity - an ongoing responsiveness towards participants in context of the researcher-participant relationship. Relational intensity involves the researcher negotiating reciprocal exchanges and exercising ethical responsibility, and thus encourages participants' open sharing of their brokering practices. The article concludes that both data intensity and relational intensity are important considerations in a focused ethnography.

\section{BROKERING PRACTICES AS INFORMAL LEARNING}

The concept of brokering offers a useful lens to understand how students engage in informal academic learning. As a broad sociological concept, brokering refers to the facilitation of transferring resources from one entity to another, over gaps in social structure. That is, brokering occurs when an intermediary, the broker, assists in the transfer or exchange of valued resources such as services, information, opportunities and/or knowledge, where the recipient of such assistance would have had difficulty accessing these resources in the first place (Stovel et al. 2011). The gaps, or the difficulty of direct access to those holding such resources, stem from differences in language and culture or the complexity of interaction between communities. It is the broker who has connections to these separated communities that facilitate interactions and transfer of resources between them.

It is not surprising, then, for the brokering concept to be found in literature on language and literacy learning among immigrant communities (Alvarez 2012; Hall and Sham 2007; Jones and Trickett 2005; Orellana et al. 2003; Perry 2009; Tse 1995, 1996). Such learning is part of people's everyday practices and often takes place within the community. The term language brokering, for example, has been defined as 'interpreting and translating performed by bilinguals in daily situations without special training' (Tse 1996: 48). Often, children who develop their English language proficiency in school, become brokers for their parents who often have limited language skills. They translate and interpret a range of documents including notices from school, bank statements, immigration forms and job applications. A related concept of literacy brokering refers to not only a literal understanding of unfamiliar texts and practices, but also their underlying meanings and implications (Perry 2009). For example, in Perry's (2009) research on Sundanese refugee families in the United States, the broker explained to the immigrant family that an unsolicited letter suggesting that the recipients won a million dollars was, in fact, not a genuine offer, but instead was potentially an act of fraud that directed recipients to part with their own money for nothing in return. 
As brokering takes place in everyday contexts, it can also be understood as an aspect of informal learning, which has been recognized to be an important and integral part of academic learning (Barron 2006; Barnett 2007). Informal learning is learning that takes place in the absence of externally imposed objectives and standards; such learning experiences are highly personalized and therefore relevant to the learner's particular needs (Livingstone 2006). In fact, informal learning may very well be a response to the barriers posed by formal learning such as inappropriate delivery of formal instruction and learner's low self-confidence (McGivney 1999). In the context of international EAL students, barriers to academic learning are widely acknowledged to be related to inadequate English language proficiency and cultural differences (Borland and Pearce 2002; Johnson 2008; Lee et al. 2013), as well as a lack of social interaction between international students and the host community (Sawir et al. 2008; Ward and Masgoret 2004; Ward et al. 2009). While there is a wide range of concepts of informal learning such as self-directed learning, networking, coaching and mentoring (Eraut 2004; Marsick and Watkins 2001), these concepts are predominantly related to the workplace context, and therefore may not adequately capture the informal academic learning practices among students, especially when understanding informal learning as a response to barriers in formal learning.

Brokering thus can then be understood as a concept of informal learning that bridges the gaps in a social and cultural environment that is different from students' countries of origin. In this research, brokering practices are defined as help-seeking social interactions outside the formal curriculum where EAL students seek access to academic resources, such as understanding unfamiliar texts, interactions, artefacts, and social and cultural practices encountered in the context of the host academic community. Specific brokering interactions may involve translating or interpreting academic-related information, or making explicit the requirements of academic assignments.

\section{BROKERING PRACTICES IN HIGHER EDUCATION}

Brokering practices, or help-seeking social interactions, however, are not well understood as informal academic learning practices. While informal social interactions are acknowledged to contribute to students' classroom learning (Boud et al. 2001; Jarvela 2011; Newman 2002; Topping 2005), much of educational research focuses on classroom learning, thus overlooking the significance of learning that takes place outside the prescribed curriculum (Richards 2015; Rogers 2008).

Nonetheless, brokering has been alluded to in a wide range of studies that examine informal academic-related social interactions in higher education, even if the term is not used. Several studies recognize the importance of learning outside the classrooms, whether as face-to-face peer interactions in groups (Goodwin et al. 2010; Krause 2007), or through technology-mediated means such as social networking sites (Madge et al. 2009; Vivian et al. 2014). With respect to international EAL students, students' social networks appear to be an important resource for seeking help for interpreting and completing assignments (Li et al. 2010; Montgomery and McDowell 2009; Wakimoto 2007; Zappa-Hollman and Duff 2015), with several studies examining how students get assistance with their academic writing (Che 2013; Nam and Beckett 2011; Séror 2011). Brokering interactions among peers also appear important for gaining an understanding how to interact with instructors and peers in the host academic community (Li and Collins 2014; Seloni 2012).
1. 2. 3. 4. 5. 6. 7. 8. 9. 10. 11. 12. 13. 14. 15. 16. 17. 18. 19. 20. 21. 22. 23. 24. 25. 26. 27. 28. 29. 30. 31. 32. 33. 34. 35. 36. 37. 38. 39. 40. 41. 42. 43. 44. 45. 46. 47. 48. 49. 50. 51. 52. 
The literature also suggests that brokering relationships are based on existing social relationships. EAL students may seek assistance from nativeEnglish speaking classmates or co-residents whom they perceive to have greater expertise or experience, or from peers with whom they have shared experiences such as being part of a community of international students, or similar cultural backgrounds (Che 2013; Montgomery and McDowell 2009; Seloni 2012; Zappa-Hollman and Duff 2015). In addition, brokering relationships appear to be strengthened based on overlapping connections, for example, peers who are co-nationals as well as classmates.

However, the circumstances that motivate and sustain brokering interactions and relationships remain unclear as brokering interactions themselves have not been examined in much detail. The majority of the studies were based on self-reported data such as interview responses; few studies reported using any observational methods. The lack of observational data is not surprising given the potential for brokering interactions to be fluid and unpredictable. As part of informal learning, brokering practices are taken-for-granted and relatively invisible; they are 'implicit, unintended, opportunistic and unstructured' (Eraut 2004: 250), and of which the learner is usually unaware.

Not only is it challenging to organize observations of brokering interactions, the interaction themselves may not be observable in the traditional sense. Considering the ubiquitous use of digital media for personal communication among young adults (Helles 2012; Madell and Muncer 2007; Thompson 2013), brokering may occur through digital means (e.g. mobile text messages), in addition to taking place during face-to-face communication. Because of the widespread and routine use of digital media, such communication practices are also taken-for-granted and invisible (Pink et al. 2015). Thus, brokering practices can be said to be embedded in students' everyday lives, taking place in multiple sites and media, thereby making it challenging to investigate.

\section{RESEARCHING BROKERING PRACTICES}

In light of the research gaps, the purpose of this research was to investigate the nature of brokering practices among international EAL university students with the following questions in mind:

1. What is the nature of brokering among international EAL students?

a) What aspects of academic learning are brokered?

b) Who are the participants in brokering relationships?

c) What are the reasons participants offer for engaging in brokering relationships?

d) What are the characteristics of brokering relationships?

e) What are the dynamics of the interactions that occur in the context of brokering relationships?

2. What are the consequences of brokering?

Given the invisible nature of brokering practices, the research questions were best addressed using ethnography as it 'involves direct and sustained contact with human agents in the collaborative co-construction of an account' (O'Reilly 2012: 226). Ethnography uses a range of methods but often focuses on participant observation, whereby the researcher interacts with people in everyday situations while collecting information, and in-depth interviews, to obtain a holistic perspective of the social or cultural group (Fetterman 2010). Conventionally, ethnography research is conducted over a period of twelve 
months or longer. However, in contemporary contexts where social activity and daily life take place in multiple sites and through multiple media, ethnographic research may be conducted in shorter durations and focused aspects (Madden 2010).

Ethnographic research that deals precisely with such contemporary circumstances is focused ethnography. Focused ethnography addresses specific aspects of cultural or social phenomena in a relatively short period of time because of particular circumstances or constraints of the research context (Higginbottom et al. 2013; Knoblauch 2005; Morse 2007). The term focused ethnography appears to have originated from nursing research (Higginbottom et al. 2013; Morse 2007; Muecke 1994), but more recently, it has been used to describe a distinctive form of contemporary sociological ethnography that investigates everyday social interactions (Knoblauch 2005). The main feature of focused ethnography is that it adapts conventional ethnography methods to suit the study of contemporary society which features 'differentiated divisions of labour and a highly fragmented culture' (Knoblauch 2005: par 30). While often used in applied research contexts such as health care and workplace environments, focused ethnography is nonetheless a relevant methodology for researching students' informal learning. The choice of focused ethnography was influenced by the interrelated features of the research context, namely the narrow scope of research, the specified timeframe, and the need to adapt conventional ethnographic methods.

Firstly, focused ethnography is interested in specific aspects of, rather than whole communities and cultures (Higginbottom et al. 2013; Knoblauch 2005). Focused ethnographies attend to particular aspects such as humancomputer interaction in the workplace environment (e.g. Millen 2000), and perceptions and experiences of a particular demographic group in healthcare (e.g. Higginbottom 2006). Similarly, this research was interested in a relatively narrow aspect of EAL students' learning, i.e. brokering practices, as opposed to all aspects of their informal learning.

Secondly, instead of being immersed in the ongoing social life of the research participants, the researcher remains in the field for a relatively short period of time, or for specific time periods (Higginbottom et al. 2013; Knoblauch 2005). The limited period of researcher engagement is related to the particular phenomenon or the constraints or boundaries in the research context. In an example in workplace research, researchers focused on a series of meetings, each lasting around three hours (Gkeredakis et al. 2014). In another example in healthcare research, the ability for researchers to remain in hospital wards was curtailed by hospital protocols where 'care and treatments have priority over data collection activities' (Morse 2007: 864-65). In this research, the timeframe for investigating brokering practices was restricted to students' initial academic semester (fifteen weeks). This initial period of studies is one where students are most likely to require assistance with their academic learning, as it is also the time period where they experience the greatest challenge in adjusting to a new environment (Ward et al. 1998; Hechanova-Alampay et al. 2002).

Finally, as a result of a narrow research focus and its associated constraints described previously, conducting participant observations and long unstructured interviews may not be possible. Instead, conventional ethnographic methods are adapted. For example, researchers may conduct intermittent instead of prolonged field visits, as well as shorter and more structured interviews (Higginbottom et al. 2013). When observations are feasible, the
1. 2. 3. 4. 5. 6. 7. 8. 9. 10. 11. 12. 13. 14. 15. 16. 17. 18. 19. 20. 21. 22. 
researcher may take on an observer rather than a participant role; and when not practicable, they are omitted (Morse 2007; Higginbottom et al. 2013). Furthermore, investigating the details of social interactions may be more suitably achieved through sound and/or visual recordings of those interactions rather than direct observation (Knoblauch 2005; Pink and Morgan 2013). In this research, adapting conventional ethnographic methods was necessary to investigate brokering practices that were potentially fluid and unpredictable. Instead of the researcher being immersed in a single setting, conducting intermittent observations and interviews were thought to be more appropriate. Furthermore, the likelihood of brokering practices including digitally mediated communication such as mobile text messages suggested the use of digital ethnographic methods (e.g. capturing screenshots of text message interactions) in place of traditional participant observation (Boellstorff et al. 2012; Pink et al. 2015).

\section{TENSIONS IN USING FOCUSED ETHNOGRAPHY}

While focused ethnography addresses the specific features of contemporary research contexts and interests, there are nonetheless tensions in such shortterm ethnography, the main challenge being collecting meaningful data in a short period of time (Brockmann 2011; Jeffrey and Troman 2004; Muecke 1994). Ethnography stresses the active involvement of the researcher in a full range of social interactions of the target community, not only to produce a rich account of the people and/or phenomenon studied, but also to the extent of allowing contradictory behaviours and perspectives to emerge ( $\mathrm{O}^{\prime}$ Reilly 2012). Thus the credibility of focused ethnographies depends on the researcher having sufficient personal involvement in the life-space of the research participants (Muecke 1994).

In response to the challenge of having sufficient personal involvement in short-term field work, proponents of focused ethnography have pointed out that the short time period is compensated by its intensity in the data collection and analysis processes (Knoblauch 2005; Pink and Morgan 2013), otherwise termed data intensity. Data intensity is achieved through the use of audio-visual recording devices which can potentially produce a large amount of verbatim data (e.g. voice or video recordings) which can then be closely analysed.

The argument of data intensity, however, does not fully address the challenge of maximizing researchers' personal involvement in their participants' lives. While an abundance of data is beneficial in accounting for the details of participants' social lives, it is also important to consider the implications of obtaining such data in the first place. For researchers to be able to closely examine people's behaviours, participants themselves need to be willingly open to scrutiny, and their willingness is dependent on the quality of the researcher-participant relationship. In order to strengthen researchers' engagement with participants, another form of intensity is involved - relational intensity - what I refer to as the researchers' responsiveness towards participants in the context of the researcher-participant relationship. Whereas data intensity highlights the quantity of data and analytical activity (Knoblauch 2005), relational intensity emphasizes the quality of the researcher-participant relationship. Developing relationships based on trust and mutual understanding is integral to obtaining relevant data from research participants ( $\mathrm{O}^{\prime}$ Reilly 2012). Relationship building not involves building rapport with others, but 
also managing the demands and tensions that arise from the researcher's ongoing negotiation of access to data (Mills and Morton 2013). While managing researcher-participant relationships is a fundamental aspect of all ethnography, the intensity of doing so is heightened within a short time period, and especially when the aim is to examine personal or sensitive areas of participants' lives (Higginbottom et al. 2013; Pink and Morgan 2013). Hence, in a research context marked by temporal and other types of constraints, articulating how the researcher maintains relational intensity is important for demonstrating the extent of the researcher's involvement with participants. In doing so, researchers need to be reflexive, that is, recognize the influence of their thoughts, actions and attitudes on the research, and in this case, the influence they have in forming relationships with participants (O'Reilly 2012).

\section{FOCUSED ETHNOGRAPHY IN PRACTICE}

In using focused ethnography in my research, there were tensions in attempting to collect sufficient and relevant data, particularly data directly related to brokering interactions, not only because of time constraints, but also because of the difficulty in accessing peoples' personal spaces where brokering took place. Nonetheless, these tensions were addressed by efforts to achieve data intensity and maintaining relational intensity. The use of mobile communication devices and its visual recording technology in particular contributed to a substantial portion of data directly linked to brokering interactions, thus achieving data intensity for this particular type of data. I have also found that maintaining relational intensity was challenging, but nonetheless important in accessing meaningful data. In discussing how tensions of focused ethnography were addressed in my research, I first present an overview of my research methodology, followed by highlighting the use of digital ethnographic methods, and finally, offer a reflexive account of my relationships with participants.

\section{Background of research context and participant recruitment}

The research was conducted at a university in New Zealand. The university is made up of seven faculties and schools, with around 2000 international students which make up around 15 per cent of the student population. International students enrolled in tertiary programmes of study at the university come through primarily in two ways: directly from their home country, or after completing qualifying English and/or academic programmes in New Zealand.

My target sample was international students who were enrolled in a tertiary level programme (i.e. not foundational studies or other pre-sessional programmes) and for whom English was an additional language. I was also specifically interested in students who were in their initial semester of studies. Because of the relatively short time period of fifteen weeks in an academic semester, it was important to have my target number of participants early on in the semester, instead of allowing participants to be recruited mid-way through or later in the semester. I aimed at recruiting ten participants, a number that a single researcher could practically manage in terms of conducting regular individual interviews over a period of fifteen weeks.

To maximize the number of students recruited in a timely fashion, my primary strategy was to recruit participants from four courses that typically had international students enrolled. Before the start of the first lecture for each course, I made an announcement about my research, and invited international
1. 2. 3. 4. 5. 6. 7. 8. 9. 10. 11. 12. 


\begin{tabular}{|c|c|c|c|c|c|}
\hline Name & Gender & Age & Home country & Level of study & English entry qualification \\
\hline Kim & $\mathrm{F}$ & Early 20s & Taiwan & $\begin{array}{l}\text { Postgraduate } \\
\text { diploma, first year, } \\
\text { first semester } \\
\text { (Completed Bachelor } \\
\text { in Taiwan) }\end{array}$ & $\begin{array}{l}\text { English language programme } \\
\text { in NZ }\end{array}$ \\
\hline Linda & F & Early 20s & China & $\begin{array}{l}\text { Postgraduate } \\
\text { diploma, first year, } \\
\text { first semester } \\
\text { (Completed Bachelor } \\
\text { in China) }\end{array}$ & IELTS in home country \\
\hline Josh & M & Early 20s & $\begin{array}{l}\text { Malaysia } \\
\text { (Chinese } \\
\text { ethnicity) }\end{array}$ & $\begin{array}{l}\text { Honours year, first } \\
\text { semester } \\
\text { (Completed Bachelor } \\
\text { in Malaysia) }\end{array}$ & $\begin{array}{l}\text { English medium university in } \\
\text { home country }\end{array}$ \\
\hline Jane & $\mathrm{F}$ & Early 20s & China & $\begin{array}{l}\text { Undergraduate, first } \\
\text { year, first semester }\end{array}$ & IELTS in home country \\
\hline Sarah & $\mathrm{F}$ & Early 20s & China & $\begin{array}{l}\text { Undergraduate, first } \\
\text { year, first semester }\end{array}$ & $\begin{array}{l}\text { English language programme } \\
\text { in NZ }\end{array}$ \\
\hline Henry & M & Early 20s & China & $\begin{array}{l}\text { Undergraduate, first } \\
\text { year, first semester }\end{array}$ & $\begin{array}{l}\text { University preparatory } \\
\text { programme in NZ }\end{array}$ \\
\hline Annie & $\mathrm{F}$ & Early 30s & China & $\begin{array}{l}\text { Undergraduate, first } \\
\text { year, first semester }\end{array}$ & $\begin{array}{l}\text { English language programme } \\
\text { in NZ }\end{array}$ \\
\hline Kevin & M & Early 40s & China & $\begin{array}{l}\text { Undergraduate, first } \\
\text { year, first semester }\end{array}$ & IELTS in home country \\
\hline Cindy & $\mathrm{F}$ & Early 20 s & Japan & $\begin{array}{l}\text { Undergraduate, } \\
\text { first semester of an } \\
\text { exchange programme }\end{array}$ & TOEFL in home country \\
\hline Simon & M & Early $20 \mathrm{~s}$ & China & $\begin{array}{l}\text { Undergraduate, first } \\
\text { year, second semester }\end{array}$ & $\begin{array}{l}\text { English language programme } \\
\text { in home country }\end{array}$ \\
\hline
\end{tabular}

Table 1: Summary of participants' background.

EAL students to a research information session where I would explain my research in more detail. An additional strategy was to recruit students from orientation events for international students. I attended several of such events and when the opportunities arose (e.g. while waiting for the event to being), I introduced myself and asked students if they were interested in participating in my research.

The international student population at the university mostly came from countries in the Middle East and Asia. While I did not intend to recruit participants from a particular country or region, all my participants were from Asia, with the majority of Chinese ethnicity. This was not surprising since I myself am of Chinese ethnicity (from Singapore). Furthermore, even though I used English in my various interactions with prospective participants, I was able to converse in Mandarin with Chinese students who preferred to speak in their native language. The recruitment took place over two weeks and at the end of which, I had ten participants. All of them had a chance to listen to 
my explanation of the research by referring to the information letter, had an opportunity to ask questions, and signed the consent form. The agreement to participate in the study was documented and officiated as per the requirements of my university's research ethics committee. Table 1 provides a summary of the background information of the participants.

\section{Data collection methods}

My research design took into consideration several important features of brokering practices in this research context:

i) Unfamiliarity: Participants were in a new environment and commencing their academic studies and may not readily identifying brokering interactions;

ii) Unpredictability: Brokering as an informal activity is likely to occur spontaneously or planned with short notice. Thus, regular contact with participants was crucial in order to enquire about brokering interactions and identify potential interactions for observation before they happen;

iii) Unease: Observations of participants' interactions with their brokers were likely to be perceived as intrusive and so there needed to be flexible negotiations as to how I could access the interactions and related artefacts.

17.

The two primary methods commonly associated with ethnography are observation and unstructured interviewing (Creswell 2012). These are often supported by documents, records, and artefacts related to the research context (Patton 2015). As highlighted earlier, focused ethnography employs similar data collection methods but with some key differences. In adapting conventional ethnographic methods, I conducted interviews that were more tightly structured with specific aims in mind, and took on an observant role during observations (Higginbottom et al. 2013). Furthermore, the availability and affordances of recording technologies allowed for participant activity to be recorded without the physical presence of the researcher (Knoblauch 2005; Pink and Morgan 2013). Specifically, I adopted digital ethnographic methods to obtain data on interactions that took place via digitally mediated communication (Boellstorff et al. 2012; Pink et al. 2015). In place of conducting observations, I asked participants to capture images of the messages they exchanged with their brokers using the camera function on their own digital devices such as the mobile phone. Table 2 outlines my choice of data collection methods, how the method was carried out, and the research questions addressed.

Conducting regular interviews was the primary data collection method in terms of obtaining information that addressed most of the research questions. Having regular contact with participants allowed me to probe into potential brokering practices, and ask participants if I could meet their brokers and observe their interactions. Thus, the process of conducting interviews was not just about collecting information, but it also involved pursuing opportunities to engage with participants' brokers and exploring ways to access their brokering interactions.

However, it was challenging to gain access to participants' brokering interactions for several reasons. Within the timeframe of an academic semester, I had to take into account that I had multiple participants, that there were more opportune moments than others to observe brokering interactions (e.g. nearing an assignment deadline), and that the need for academic brokering 
Using focused ethnography to understand ...

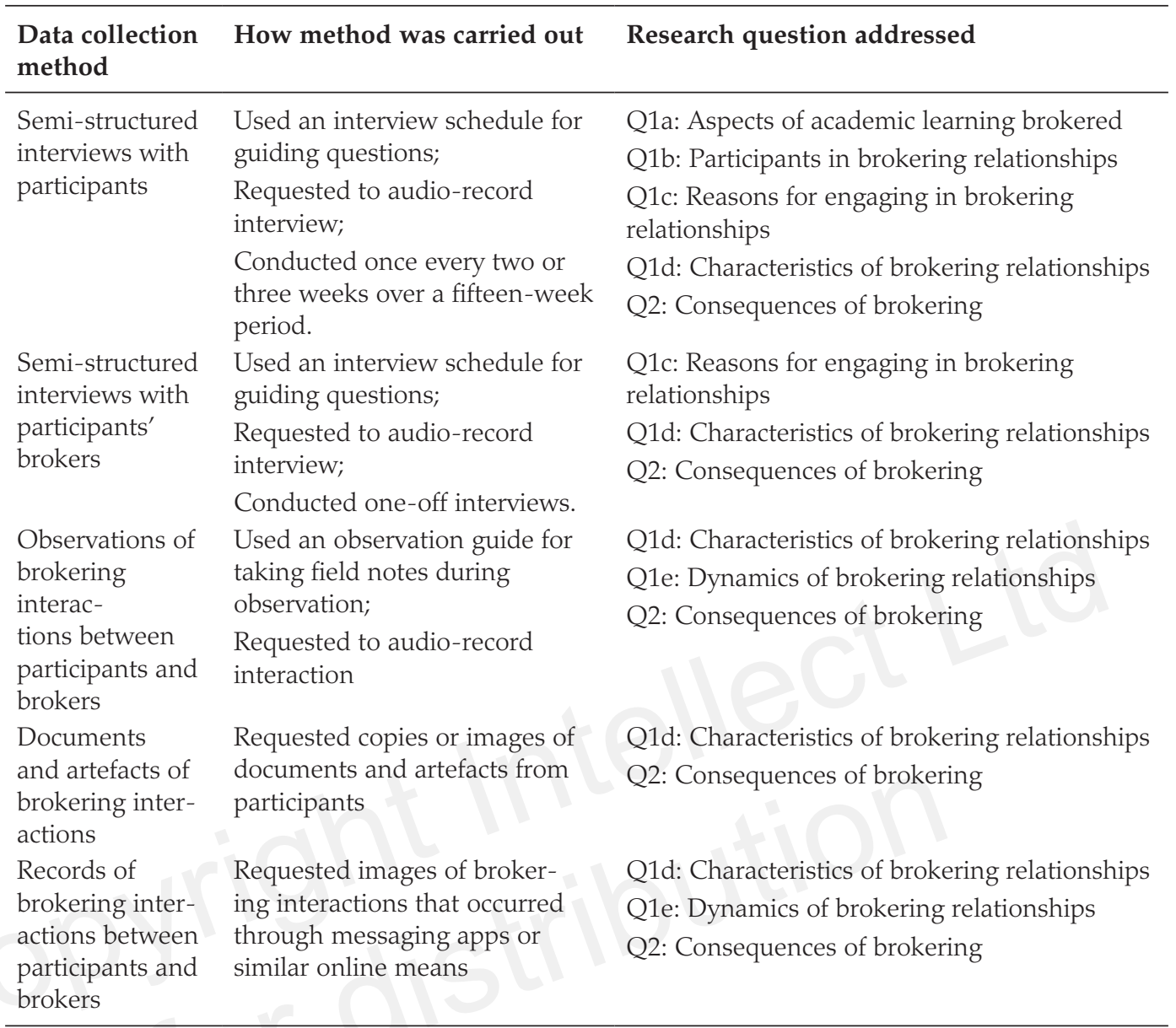

Table 2: Overview of data collection methods.

would diminish when the semester concluded. Furthermore, participants and their brokers were not always prepared to allow me access into their personal spaces. Thus, instead of pursuing every potential brokering interaction that participants shared with me, I followed up on opportunities that were most likely to yield relevant data. Managing the constraints of the research context resulted in the forms of intensity raised earlier in the discussion of focused ethnography - data intensity and relational intensity.

\section{DATA INTENSITY THROUGH DIGITAL ETHNOGRAPHIC METHODS}

In talking about data intensity, I refer to data that is specific to brokering interaction, that is, data that provides verbatim record of brokering interactions. Obtaining such data was challenging as it was difficult to access these brokering interactions in the first place. Participants mentioned a variety of brokering interactions during interviews, for example, talking to classmates after class, studying with others in the library, and exchanging messages with 
friends on the mobile phone. However, many of these brokering interactions were spontaneous and/or appeared to be one-off brokering interactions. Thus, it was challenging to organize observations of brokering interactions in advance.

Among the brokering interactions that were discussed with participants during interviews, those that occurred via mobile phone applications had the potential of being the most accessible. Using digital ethnographic methods, I obtained records of 33 instances of brokering interactions that occurred in these mobile phone applications, compared to observing and audio-recording just two instances of face-to-face interactions.

Digital ethnographic methods do not only refer to using digital technology to collect data; it also involves researchers as part of the digital communication practices they seek to investigate (Pink et al. 2015). As all my participants were regular users of mobile communication applications such as WeChat and Facebook Messenger, I used those applications in my informal communication with them, such as scheduling interviews and asking follow-up questions. Messages sent through these applications usually received their immediate attention and were the preferred mode of communication for participants. As I interacted with them through these applications, and as my awareness and understanding of their digital communication practices increased, I explored mobile and computer interactions when probing into potential brokering practices.

Participants' digitally mediated brokering interactions took place as exchanges of multimedia messages (mostly text with occasional use of visual and audio attachments). As these exchanges were retained on the mobile phone, participants were able to easily retrieve them. Participants provided me a copy of the exchanges by taking screenshots of the messages (i.e. using the photo capability in the phone to create an image of what appears on the mobile phone screen), and then sent them to me, often using the mobile communication tools I was already using with them. Thus, the relatively easy access to such data was facilitated, in part, by my participation in the same digital communication practices of my participants.

Two participants in particular, Kim and Linda, provided the majority of the screenshot data. Kim provided fourteen instances of brokering interactions with her broker; these interactions were mostly in Chinese, and covered a range of topics over the period of the semester. Linda, on the other hand, provided a total of eighteen brokering instances, eight instances in English and associated with one particular broker, and ten instances in Chinese and associated with another broker. The data I obtained from using digital ethnographic methods thus enabled me to analyse brokering interactions in detail with respect to three different brokering relationships. Aligned with the broader ethnographic goal of gaining a holistic perspective of brokering practices, these digital-visual records were not analysed in isolation, but in relation to other data collected such as interviews with Kim and Linda, as well as interviews with their respective brokers.

It should also be noted that while much of the direct evidence of brokering interactions existed in the form of visual records of digital communication, digitally mediated brokering interactions were part of a range of brokering practices across participants with varying educational backgrounds, learning dispositions, and in different academic programmes. Table 3 provides a summary of the various types of data that provide evidence of brokering practices. As this table also shows, brokering artefacts and records
1.

2.

3.

4.

5.

6.

7.

8.

9.

10.

11.

12.

13.

14.

15.

16.

17.

18.

19.

20.

21.

22.

23.

24.

25.

26.

27.

28.

29.

30.

31.

32.

33.

34.

35.

36.

37.

38.

39.

40.

41.

42.

43.

44.

45.

46.

47.

48.

49.

50.

51.

52. 
Using focused ethnography to understand ...

\begin{tabular}{|c|c|c|c|}
\hline Data collection method & Type of data & $\begin{array}{l}\text { Data associated with } \\
\text { which participants }\end{array}$ & $\begin{array}{l}\text { Perspective } \\
\text { derived from }\end{array}$ \\
\hline Interview with participants & $\begin{array}{l}\text { Self-report of brokering } \\
\text { interactions }\end{array}$ & All participants & Participant \\
\hline $\begin{array}{l}\text { Interview with partici- } \\
\text { pants' brokers }\end{array}$ & $\begin{array}{l}\text { Self-report of brokering } \\
\text { interactions }\end{array}$ & Kim, Linda, Jane & Broker \\
\hline $\begin{array}{l}\text { Copies of participants' } \\
\text { draft writing with } \\
\text { comments from learning } \\
\text { support tutors }\end{array}$ & $\begin{array}{l}\text { Textual artefacts of } \\
\text { brokering interaction }\end{array}$ & Kim, Linda, Jane & Researcher \\
\hline $\begin{array}{l}\text { Screenshots of messaging } \\
\text { exchanges between } \\
\text { participant and broker }\end{array}$ & $\begin{array}{l}\text { Textual-visual evidence } \\
\text { of brokering interaction }\end{array}$ & Kim, Linda, Jane & Researcher \\
\hline $\begin{array}{l}\text { Observation and audio- } \\
\text { recording of interactions } \\
\text { between participant and } \\
\text { broker }\end{array}$ & $\begin{array}{l}\text { Observation notes and } \\
\text { aural evidence of } \\
\text { brokering } \\
\text { interaction }\end{array}$ & Jane & Researcher \\
\hline
\end{tabular}

Table 3: Summary of evidence of brokering interactions.

of brokering interactions were obtained from specifically three participants Kim, Linda and Jane. In understanding the nature of brokering practices, however, it was important to take into account all the data collected from all participants. Brokering practices that were discussed during interviews were not always open to scrutiny. Furthermore, just as evidence of brokering interactions were important to understanding the nature of brokering, so were understanding the circumstances and reasons for the lack of brokering practices.

Thus, data intensity, while relevant and necessary for understanding digitally-mediated brokering interactions, was not applicable to other types of brokering interactions. In terms of using focused ethnography to investigate practices that are not easily noticed and occurring in personal spaces, it may be appropriate to address other forms of intensity that contribute to enhancing the researcher's involvement in participants' social spaces.

\section{RELATIONAL INTENSITY}

Relational intensity, as mentioned earlier, refers to the researcher's ongoing responsiveness towards participants in the context of the researcher-participant relationship. While relational intensity does not necessarily increase the amount of data obtained, nor guarantee greater exposure to participants' lives, attending to participants' needs lays the foundation for ethically sound researcher-participant relationships that increase participants' confidence in the researcher (Corbin and Morse 2003; Mills and Morton 2013). This is especially important in a focused ethnography where time constraints and other demands can easily augment the need for data while diminishing the importance of research subjects. Mills and Morton (2013) highlight that ethnographic fieldwork requires researchers to negotiate the complexities of social relationships between researchers and their participants. For example, the 
researcher is faced with ethical decisions regarding reciprocity, that is, what the researcher offers in return for what the participants contribute, as well as responsibilities towards participants. In discussing relational intensity in my research, I examine how relationships with participants were cultivated, as well as how reciprocity and responsibilities were negotiated in the context of the relationships.

With no prior connection with my participants, I was conscious of the importance of building and maintaining relationships with them. While maintaining informal communication channels as previously mentioned was helpful, the main opportunity for building relationships was during regular interviews with participants (Oakley 1981). Furthermore, interviews were semi-structured in that they were guided by a set of prompts but were used flexibly, allowing both the researcher and participant to bring up additional questions and topics (Corbin and Morse 2003). Thus, regular contact and a flexible interview style allowed me to increase my familiarity with participants in a short period of time.

In the context of interviews, the researcher-participant relationship could be further viewed as an opportunity for reciprocal exchange that is beneficial to the participant as it is to the researcher (Corbin and Morse 2003). While the researcher benefits by obtaining required data and meeting other research goals, participants benefit in less obvious but nonetheless important ways. One benefit to participants, for example, is being able to make sense of what is happening to them by talking about events and emotions. Several participants shared this view when I asked them about what they found useful by participating in my research. Kim and Linda, for example, shared that they found it helpful to talk to someone about what was troubling them; by articulating their thoughts, they were able to work through their problems. Similarly, Jane viewed the relationship as akin to counselling, sharing with me that she regarded me as a confidante.

Engaging in reciprocity, however, is not as straightforward as being in a mutually beneficial exchange. Participants may also be seeking particular information from the researcher and 'a conscientious researcher will try to discern what it is participants are seeking' (Corbin and Morse 2003: 342) and explore the possibility of providing it to them. However, my ability to reciprocate in this manner was often challenged by the very research topic itself. Because I was investigating participants' brokering practices with others, I did not want to set up an expectation that I would be ready to offer help, and thus implicate myself as their broker. So when participants requested advice related to their academic work or learning, my response was usually a guarded one - I would not avoid an answer, but suggested resources they could use or people they could ask. Even when questions did not relate to academic learning, for example, asking for my opinion about a particular personal situation, I was just as cautious in offering a response for the same reasons. It was thus a delicate balance of providing a response of some value without affecting what I considered to be the integrity of the research.

On the other hand, participants themselves may be deterred from responding to the researcher if uncomfortable feelings and emotions are evoked (Corbin and Morse 2003). This was the case in my research where I frequently made intrusive requests - asking participants if I could meet their friends and if I could read their messages. As brokering interactions were often related to course-related tasks and assignments, these requests also increased as the semester progressed. There were several occasions when
1.

2.

3.

4.

5.

6.

7.

8.

9.

10.

11.

12.

13.

14.

15.

16.

17.

18.

19.

20.

21.

22.

23.

24.

25.

26.

27.

28.

29.

30.

31.

32.

33.

34.

35.

36.

37.

38.

39.

40.

41.

42.

43.

44.

45.

46.

47.

48.

49.

50.

51.

52. 
1. participants did not want me to observe them with particular friends or read 2. their messages. Participants gave the reason that their friends would be annoyed or embarrassed, or shared that they themselves were uncomfortable with my requests. There is thus some measure of emotional risk for participants in engaging in a reciprocal exchange. In response, I became more sensitive to participants' level of comfort with particular brokers and refrained from repeating requests for observation and records.

In addition to engaging in reciprocal exchanges with sensitivity and respect, it was also important to exercise responsibility towards participants as part of research and personal ethics, in particular, the need to 'maintain confidentiality, ... and to provide for the personal safety and well-being of participants' (Corbin and Morse 2003: 349). Responsibility towards research participants was also extended to others who were implicated in participants' brokering interactions. When participants granted me access to their brokering interactions, especially when providing me screenshots of their online interactions, I had to ask participants' brokers for permission. Although participants often communicated to me their brokers' consent, I was not satisfied unless I could meet them in person to explain my research and give them the consent form to sign. Although this process of informed consent was expected as part of the ethics approval, the ease with which images could be recorded and shared meant that I had to exercise additional caution in managing the information participants shared with me. There were a few instances where I was not able to contact the participants' brokers successfully in the manner I describe. In those cases, I declined the offer of screenshots, or deleted the images sent to me, even though the participants themselves thought that there was nothing wrong in using them.

Even after I had received signed consent from all involved in the brokering interactions I observed or had visual records of, it was then important to carefully anonymize details in transcripts and visual records that potentially revealed the participants and their brokers' identities. Details such as reference to courses, lecturers and other classmates potentially revealed information that may have unintended and negative consequences towards research participants or the even the broader research context (Tracy 2010). Although these acts of responsibility were not immediately of value to participants as much as responding to their requests and questions would have been, not acting responsibly could have easily undermined the research.

Maintaining relational intensity thus involved establishing regular contact through a series of interviews, negotiating reciprocal exchanges, and fulfilling ethical responsibilities towards participants. It was this conscious and ongoing effort in attending to participants' needs and well-being which encouraged participants' open sharing during interviews and willingness to have their interactions examined. Seen in this light, relational intensity can be said to facilitate data intensity. Without meaningful researcher-participant relationships, participants may not have been amenable to having their personal interactions observed or recorded. This is not to say that relational intensity was more important than data intensity. Data intensity compensates for the short period of research activity with a large quantity of data, while relational intensity demonstrates a high degree of researcher involvement in responding to participants' needs. In addressing the potential lack of participant engagement in a focused ethnography, having both forms of intensity were important in achieving a holistic understanding of participants' brokering practices. 


\section{CONCLUSION}

Focused ethnography emerged from a contemporary need to understand a diversified society. It is primarily ethnographic in its goal to understand the nature of behaviour and attitudes. It is necessarily focused to respond to the features of the research setting. While data intensity has been argued to compensate for a relative short time in the field, it may only apply to certain types of social practices and interactions. Other aspects of intensity should also be discussed in enhancing researcher engagement in the research field. This research has found relational intensity to be important in cultivating ethical researcher-participant relationships that in turn foster meaningful data collection. It is hoped that future research employing focused ethnography explores both data-related and relational forms of intensity that arise in the process of conducting research bounded by temporal and other constraints.

\section{ACKNOWLEDGEMENTS}

The author acknowledges the University of Waikato for the provision of a Doctoral Scholarship that supported the research. The author is also grateful to colleagues and advisers, two anonymous reviewers and the journal editor for constructive feedback on earlier drafts of this article.

\section{REFERENCES}

Alvarez, Steven (2012), 'Language brokering in practice: Linguistic power, biliteracy events, and family life', in P. M. Chamness, J. L. Watzke and M. Mantero (eds), Readings in Language Studies, vol. 3, Grandville, MI: International Society of Language Studies, pp. 151-73.

Barnett, Ronald (2007), 'Life-wide education: A new and transformative concept for higher education?', in Proceedings of Enabling a More Complete Education: Encouraging, Recognising and Valuing Life-Wide Learning in Higher Education, pp. 1-12.

Barron, Brigid (2006), 'Interest and self-sustained learning as catalysts of development: A learning ecology perspective', Human Development, 49: 4, pp. 193-224.

Boellstorff, T., Nardi, B., Pearce, C. and Taylor, T. L. (eds) (2012), Ethnography and Virtual Worlds: A Handbook of Method, Princeton, NJ: Princeton University Press.

Borland, Helen and Pearce, Amanda (2002), 'Identifying key dimensions of language and cultural disadvantage at university', Australian Review of Applied Linguistics, 25: 2, pp. 101-27.

Boud, D, Cohen, R. and Sampson, J. (2001), Peer Learning in Higher Education: Learning From and with Each Other, Abingdon: Routledge.

Brockmann, Michaela (2011), 'Problematising short-term participant observation and multi-method ethnographic studies', Ethnography and Education, 6: 2, pp. 229-43.

Che, Jing (2013), 'How peer social worlds shaped the out-of-class learning experiences of college esol students: Examining the impacts of informal peer learning upon their writing and related psychosocial development', doctoral dissertation, Rochester, NY: University of Rochester.

Corbin, Juliet and Morse, Janice M. (2003), "The unstructured interactive interview: Issues of reciprocity and risks when dealing with sensitive topics', Qualitative Inquiry, 9: 3, pp. 335-54.
1.

2.

3.

4.

5.

6.

7.

8.

9.

10.

11.

12.

13.

14.

15.

16.

17.

18.

19.

20.

21.

22.

23.

24.

25.

26.

27.

28.

29.

30.

31.

32.

33.

34.

35.

36.

37.

38.

39.

40.

41.

42.

43.

44.

45.

46.

47.

48.

49.

50.

51.

52. 
Creswell, John W. (2012), 'Ethnographic designs', in Educational Research: Planning, Conducting, and Evaluating Quantitative and Qualitative Research, Boston, MA: Pearson, pp. 461-500.

Eraut, Michael (2004), 'Informal learning in the workplace', Studies in Continuing Education, 26: 2, pp. 247-73.

Fetterman, David M. (2010), Ethnography: Step-by-Step, 3rd ed., Los Angeles: Sage.

Gkeredakis, E., Nicolini, D. and Swan, J. (2014), 'Moral judgments as organizational accomplishments: Insights from a focused ethnography in the English healthcare sector', in F. Cooren, E. Vaara, A. Langley and H. Tsoukas (eds), Language and Communication at Work: Discourse, Narrativity, and Organizing, Oxford: Oxford University Press: pp. 293-324.

Goodwin, K., Kennedy, G. and Vetere, F. (2010), 'Getting together out-ofclass: Using technologies for informal interaction and learning', in C. H. Steel, M. J. Keppell, P. Gerbic and S. Housego (eds), Curriculum, Technology \& Transformation for An Unknown Future: Proceedings ascilite Sydney 2010, Brisbane: University of Queensland, pp. 387-92.

Hall, Nigel and Sham, Sylvia (2007), 'Language brokering as young people's work: Evidence from Chinese adolescents in England', Language and Education, 21: 1, pp. 16-30.

Hechanova-Alampay, R., Beehr, T. A., Christiansen, N. D. and Horn, K. R. Van (2002), 'Adjustment and strain among domestic and international student sojourners: A longitudinal study', School Psychology International, 23: 4, pp. 458-74.

Helles, Rasmus (2012), 'Personal media in everyday life', in K. B. Jensen (ed.), A Handbook of Media and Communication Research: Qualitative and Quantitative Methodologies, New York: Routledge, pp. 334-51.

Higginbottom, Gina Marie Awoko (2006), "'Pressure of life": Ethnicity as a mediating factor in mid-life and older peoples' experience of high blood pressure', Sociology of Health and Illness, 28: 5, pp. 583-610.

Higginbottom, G. M. A., Pillay, J. J. and Boadu, N. Y. (2013), 'Guidance on performing focused ethnographies with an emphasis on healthcare research', The Qualitative Report, 18: 17, pp. 1-16, http://www. nova.edu/ssss/QR/QR18/higginbottom17.pdf. Acccessed 23 November 2016.

Jarvela, Sanna (2011), 'How does help seeking help? - New prospects in a variety of contexts', Learning and Instruction, 21: 2, pp. 297-99.

Jeffrey, Bob and Troman, Geoff (2004), 'Time for ethnography', British Educational Research Journal, 30: 4, pp. 535-48.

Johnson, E. Marcia (2008), 'An investigation into pedagogical challenges facing international tertiary-level students in New Zealand', Higher Education Research \& Development, 27: 3, pp. 231-43.

Jones, Curtis J. and Trickett, Edison J. (2005), 'Immigrant adolescents behaving as culture brokers: A study of families from the former Soviet Union', The Journal of Social Psychology, 145: 4, pp. 405-27.

Knoblauch, Hubert (2005), 'Focused ethnography', Forum Qualitative Sozialforschung/Forum: Qualitative Social Research, 6: 3, http://www.qualitative-research.net/index.php/fqs/article/view/20. Accessed 23 November 2016.

Krause, Kerri-Lee (2007), 'Beyond classroom wall: Students' out-of-class peer experiences and implications for teaching and learning', Nagoya Journal of Higher Education, 7, pp. 301-19. 


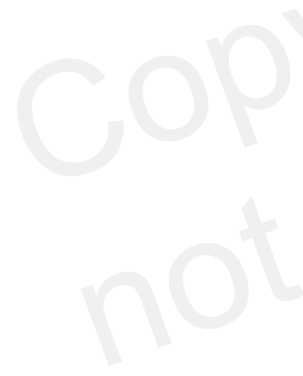

Lee, B., Farruggia, S. P. and Brown, G. T. L. (2013), 'Academic difficulties encountered by East Asian international university students in New Zealand', Higher Education Research \& Development, 32: 6, pp. 915-31.

Li, D., Clarke, D. and Remedios, L. (2010), 'Chinese students' perception of out-of-class groupwork in aAustralia', Australian Educational Researcher, 37: 3, pp. 95-112.

Li, Wendan and Collins, Christopher S. (2014), 'Chinese doctoral student socialization in the United States: A qualitative study', FIRE: Forum for International Research in Education, 1: 2, pp. 32-57.

Livingstone, D. W. (2006), 'Informal learning: Conceptual distinctions and preliminary findings', in Z. Bekerman, N. C. Burbules, and D. SilbermanKeller (eds), Learning in Places: The Informal Education Reader, New York: Peter Lang: pp. 203-27.

Madden, Raymond (2010), Being Ethnographic: A Guide to the Theory and Practice of Ethnography, London: Sage.

Madell, Dominic E. and Muncer, Steven J. (2007), 'Control over social interactions: An important reason for young people's use of the internet and mobile phones for communication?', CyberPsychology \& Behavior, 10: 1, pp. 137-40.

Madge, C., Meek, J., Wellens, J. and Hooley, T. (2009), 'Facebook, social integration and informal learning at university: "It is more for socialising and talking to friends about work than for actually doing work"', Learning, Media and Technology, 34: 2, pp. 141-55.

Marsick, Victoria J. and Watkins, Karen E. (2001), 'Informal and incidental learning', New Directions for Adult and Continuing Education, 89, pp. 25-34.

McGivney, Veronica (1999), Informal Learning in the Community: A Trigger for Change and Development, Leicester: National Institute of Adult Continuing Education.

Millen, David R. (2000), 'Rapid ethnography: Time deepening strategies for HCI field research', in Proceedings of the Conference on Designing Interactive Systems: Processes, Practices, Methods and Techniques, pp. 280-88.

Mills, David and Morton, Missy (2013), "Into the educational "field": Relationships, reciprocities and responsibilities', in Ethnography in Education, London: Sage: pp. 59-76.

Montgomery, Catherine and McDowell, Liz (2009), 'Social networks and the international student experience: An international community of practice?', Journal of Studies in International Education, 13: 4, pp. 455-66.

Morse, Janice M. (2007), 'Does health research warrant the modification of qualitative methods?', Qualitative Health Research, 17: 7, pp. 863-65.

Muecke, Majorie A. (1994), 'On the evaluation of ethnographies', in J. M. Morse (ed.), Critical issues in Qualitative Research Methods, Thousand Oaks, CA: Sage: pp. 187-209.

Nam, Miyoung and Beckett, Gulbahar (2011), 'Use of resources in second language writing socialization', The Electronic Journal for English as a Second Language, 15: 1, pp. 1-20, http://works.bepress.com/gulbahar-beckett/3/. Accessed 23 November 2016.

Newman, Richard S. (2002), 'How self-regulated learners cope with academic difficultry: The role of adaptive help seeking', Theory Into Practice, 41: 2, pp. 132-38.

Oakley, Anne (1981), 'Interviewing women: A contradiction in terms', in H. Roberts (ed.), Doing Feminist Research, London: Routledge, pp. 30-59.

O'Reilly, Karen (2012), Ethnographic Methods, 2nd. ed., Abingdon: Routledge.

2.

3.

4.

5.

6.

7.

8.

9.

10.

11.

12.

13.

14.

15.

16.

17.

18.

19.

20.

21.

22.

23.

24.

25.

26.

27.

28.

29.

30.

31.

32.

33.

34.

35.

36.

37.

38.

39.

40.

41.

42.

43.

44.

45.

46.

47.

48.

49.

50.

51.

52. 
Orellana, M. F., Dorner, L. and Pulido, L. (2003), 'Accessing assets: Immigrant youth's work as family translators or "para-phrasers"', Social Problems, 50: 4, pp. 505-24.

Patton, Michael Quinn (2015), 'Fieldwork strategies and observation methods', in Qualitative Research and Evaluation Methods: Integrating Theory and Practice, 4th ed., Los Angeles: Sage, pp. 327-420.

Perry, Kristen H. (2009), 'Genres, contexts, and literacy practices: Literacy brokering among Sudanese refugee families', Reading Research Quarterly, 44: 3, pp. 256-76.

Pink, Sarah and Morgan, Jennie (2013), 'Short-term ethnography: Intense routes to knowing', Symbolic Interaction, 36: 3, pp. 351-61.

Pink, S., Horst, H., Postill, J., Hjorth, L., Lewis, T. and Tacchi, J. (eds) (2015), Digital Ethnography: Priciples and Practice, New York: Sage.

Richards, Jack C. (2015), 'The changing face of language learning: Learning beyond the classroom', RELC Journal, 46: 1, pp. 5-22.

Rogers, Alan (2008), 'Informal learning and literacy', in B. Street and N. H. Hornberger (eds), Encyclopedia of Language and Education, 2nd ed., vol 2, New York: Springer: pp. 133-44.

Sawir, E., Marginson, S., Deumert, A., Nyland, C. and Ramia, G. (2008), 'Loneliness and international students: An Australian study', Journal of Studies in International Education, 12: 2, pp. 148-80.

Seloni, Lisya (2012), 'Academic literacy socialization of first year doctoral students in US: A micro-ethnographic perspective', English for Specific Purposes, 31: 1, pp. 47-59.

Séror, Jérémie (2011), 'Alternative sources of feedback and second language writing development in university content courses', The Canadian Journal of Applied Linguistics, 14: 1, pp. 118-43.

Stovel, K, Golub, B. and Milgrom, E. M. M. (2011), 'Stabilizing brokerage', Proceedings of the National Academy of Sciences, 108, Supplement 4, pp. 21326-32.

Thompson, Penny (2013), 'The digital natives as learners: Technology use patterns and approaches to learning', Computers and Education, 65, pp. 12-33.

Topping, Keith J. (2005), 'Trends in peer learning', Educational Psychology, 25: 6, pp. 631-45.

Tracy, Sarah J. (2010), 'Qualitative quality: Eight "big-tent" criteria for excellent qualitative research', Qualitative Inquiry, 16: 10, pp. 837-51.

Tse, Lucy (1995), 'Language brokering among latino adolescents: Prevalence, attitudes, and school performance', Hispanic Journal of Behavioral Sciences, 17: 2, pp. $180-93$.

- (1996), 'Language brokering in linguistic minority communities: The case of Chinese- and Vietnamese-American students', Bilingual Research Journal: The Journal of the National Association for Bilingual Education, 20: 3\&4, pp. 485-98.

Vivian, R., Barnes, A., Geer, R. and Wood, D. (2014), 'The academic journey and experience of university students on Facebook: An analysis of informal academic-related activity over a semester', Research in Learning Technology, 22, http://dx.doi.org/10.3402/rlt.v22.24681. Accessed 23 November 2016.

Wakimoto, Ayako (2007), 'Peer networks of international medical students in an Australian academic community', in H. E. Marriott, T. Moore and R. Spence-Brown (eds), Learning Discourses and the Discourses of Learning, Clayton: Monash University ePress, pp. 10.1-10.16, http://books. 
publishing.monash.edu/apps/bookworm/view/Learning+ Discourses+a 1. nd+the+Discourses+of+Learning/134/xhtml/chapter10.html. Accessed 2 . 23 November 2016.

Ward, Colleen and Masgoret, Anne-Marie (2004), The Experiences of International Students in New Zealand: Report on the Results of the National Survey, Wellington: Ministry of Education, http://www.educationcounts. govt.nz/publications/international/14700. Accessed 23 November 2016.

Ward, C., Masgoret, A. M. and Gezentsvey, M. (2009), 'Investigating attitudes toward international students: Program and policy implications for social integration and international education', Social Issues and Policy Review, 3: 1, pp. 79-102.

Ward, C., Okura, Y., Kennedy, A. and Kojima, T. (1998), 'The U-curve on trial: A longitudinal study of psychological and sociocultural adjustment during cross-cultural transition', International Journal of Intercultural Relations, 22: 3, pp. 277-91.

Zappa-Hollman, Sandra and Duff, Patricia A. (2015), 'Academic English socialization through individual networks of practice', TESOL Quarterly, 49: 2, pp. 333-68.

\section{SUGGESTED CITATION}

Lee, S. (2017), 'Using focused ethnography to understand brokering practices among international students', Transitions: Journal of Transient Migration, 1: 2, pp. 199-218, doi: 10.1386/tjtm.1.2.199_1

1. 3.

\section{CONTRIBUTOR DETAILS}

25.

Sherrie Lee is a Ph.D. candidate at the Faculty of Education at the University of Waikato. Her doctoral research examines informal academic learning, in particular, brokering practices, among international students at a New Zealand university. She is currently the President of the Postgraduate Students' Association and a student member of the Academic Board at the university. She was formerly a business communications lecturer at a polytechnic in Singapore. She completed her Master of Arts in Teaching (TESOL) at the University of Southern California. Her previous research examined the identity of English learners as influenced by competing discourses and social relationships.

Contact: University of Waikato, Faculty of Education, Private Bag 3105, Hamilton 3240, New Zealand.

E-mail: cs115@students.waikato.ac.nz

Sherrie Lee has asserted her right under the Copyright, Designs and Patents Act, 1988, to be identified as the author of this work in the format that was submitted to Intellect Ltd.
27.

28.

29.

30.

31.

32.

33.

34.

35.

36.

37.

38.

39.

40.

41.

42.

43.

44.

45.

46.

47.

48.

49.

50.

51.

52. 